Abstracta Iranica Abstracta Iranica

Revue bibliographique pour le domaine irano-aryen

Volume 32-33 | 2013

Comptes rendus des publications de 2009-2010

\title{
G. Del Olmo Lete. The Redaction of the Hebrew Bible: its Achaemenid Persian Setting
}

\section{Astrid Nunn}

\section{(2) OpenEdition}

1 Journals

Édition électronique

URL : http://journals.openedition.org/abstractairanica/40242

DOI : 10.4000/abstractairanica.40242

ISSN : 1961-960X

\section{Éditeur :}

CNRS (UMR 7528 Mondes iraniens et indiens), Éditions de l'IFRI

\section{Édition imprimée}

Date de publication : 1 décembre 2013

ISSN : 0240-8910

\section{Référence électronique}

Astrid Nunn, «G. Del Olmo Lete. The Redaction of the Hebrew Bible: its Achaemenid Persian Setting», Abstracta Iranica [En ligne], Volume 32-33 | 2013, document 53, mis en ligne le 01 juillet 2016, consulté le 27 septembre 2020. URL : http://journals.openedition.org/abstractairanica/40242 ; DOI : https:// doi.org/10.4000/abstractairanica.40242

Ce document a été généré automatiquement le 27 septembre 2020.

Tous droits réservés 


\section{G. Del Olmo Lete. The Redaction of the Hebrew Bible: its Achaemenid Persian Setting}

Astrid Nunn

\section{RÉFÉRENCE}

G. Del Olmo Lete. «The Redaction of the Hebrew Bible: its Achaemenid Persian Setting ». Trans. 37, 2009, p. 53-79.

1 La Bible n'aurait pas pu être écrite sans la situation socio-politique de l'empire perse, la politique achéménide étant à bon escient celle de la tolérance ethnique, culturelle et religieuse.

\section{AUTEURS}

\section{ASTRID NUNN}

Université de Munich 